\title{
Transnational Labour Solidarity as Transformative Practice: Reframing the Role of Labour Transnationalism
}

\author{
Katherine Nastovski, York University, Canada
}

\begin{abstract}
In the 1980s and 1990s, a significant number of rank-and-file trade union activists in Canada became actively engaged in various forms of international labour solidarity. This activity, the end of the Cold War and the increasing impacts of neo-liberal globalisation combined to spark hopes for greatly expanding practices of labour transnationalism. This vision of transnationalising trade union organisation has not materialised and, in fact, inside Canadian unions there has been declining faith in the possibilities of building transnational solidarity. Starting with an analysis of the dominant dichotomies underlying the literature on labour transnationalism, I suggest that stepping outside these dichotomies can provide a different way of assessing the role of transnational labour solidarity within broader struggles for workers' justice. In this article, drawing upon the case of transnational political solidarities built by workers inside Canadian unions in the 1980s and 1990s, I argue that assessing transnational practices with a longer view to class formation and the goals of workers' emancipation can help to expand conceptions of what constitutes successful transnational practice. Such a reassessment of the role of labour transnationalism is particularly timely in the current context of right-wing populism.
\end{abstract}

"Maintaining labour organization solely at the local and national level ... can never be sufficient" (Katy Fox-Hodess, 2017: 627).

While international solidarity has long been a core feature of workers' and social justice movements, the economic and political transformations that began in the mid-1970s prompted renewed concern with the limitations of organising solely within the bounds of nation states. For instance, the expansion of globalised circuits of production and care have, since the 1970s, remade life and work globally. These changes have come with serious limitations to workers' collective power and traditional strategies for resistance. It is in this context that the potential for transnational coordination between workers' organisations has re-emerged as a key area of interest for unions, activists and researchers. ${ }^{1}$

By the 1990s, an optimistic vision of moving from national silos to transnational labour organising became particularly pronounced in the Global North among trade unionists and

\footnotetext{
${ }^{1}$ I use both internationalism and transnationalism throughout the article. I use international when speaking of specific cases or periods where solidarity was viewed as inter-national and I use labour transnationalism to refer to the larger idea of solidarity across and against borders. This conception is used to encompass all forms of solidarity and coordination across borders whether primarily political, economic or social in orientation.
} 
researchers (Wells, 1998; Munck, 2002, 2010; Waterman, 2005). There were many reasons for this optimism. In North America, for instance, unions and labour activists had become active on international issues on a huge scale, particularly in opposition to free trade agreements and associated solidarity organising (Robinson, 1993, 1994; Dreiling and Robinson, 1998; Carr, 1999; Stillerman, 2003; Kay, 2005, 2011). As part of this, unions were developing transnational workerto-worker exchanges and transnational coalitions for workers' justice while joining with other civil society actors in what would develop into the anti-globalisation movement. Free trade agreements, as strategies to extend the rights of transnational corporations over those of people, underscored the urgency of finding new strategies to confront the neo-liberal offensives advanced by transnational capital. Growing awareness among trade union activists about the possible impacts of free trade agreements led to significant mobilisations of members in opposition to these agreements (Robinson, 1993, 1994; Dreiling and Robinson, 1998; Stillerman, 2003; Kay, 2005, 2011). The level of rank-and-file member participation in these efforts served as a strong basis for hope in expanding labour transnationalism. This hope was augmented by structural openings within international labour institutions brought about by the end of the Cold War. These institutions had been deeply divided ideologically even prior to the Cold War. During the Cold War the divisions were intensified as some unions moved to align more explicitly with their respective states in their efforts to undermine international left unions and governments (Zeleza, 1984; Sims, 1992; Buhle, 1999; Scipes, 2010; Nastovski, 2016b). For scholars and activists alike, the promise of transcending Cold War divisions and developing a common front among workers' organisations in the fight against neo-liberal capitalism and imperialism fed the growing optimism (Brookes and McCallum, 2017).

\section{Failure? Modest Advance? Or Something Else Entirely?}

Looking across unions within the Global North, there has been a wide range of transnational actions since the 1990s (Herod, 2001; Bieler, Lindberg and Pillay, 2008; Webster, Lambert and Bezuidenhout, 2008; Webster, 2010; Kay, 2011; Waterman, 2012; Francisco and Rodriguez, 2014; Brookes and McCallum, 2017; Taylor and Rioux, 2017). As Ronaldo Munck (2010: 228) notes, there is "little doubt that in the early 2000s international labour activity ... reached levels only dreamt of in the 1970s". This is reflected in the experimentation by unions with transnational solidarity (Marshall, 2015, 2020; Cameron, Casselman and Hoogers, 2020), and in the expansion of scholarship on Global Labour Studies. ${ }^{2}$ However, what has unfolded is far from what some had initially dreamed of (Wells, 1998). ${ }^{3}$ This is especially true of the hope that there might be significant

\footnotetext{
${ }^{2}$ Global Labour Studies (GLS) grew out of the New International Labour Studies (NILS), which emerged in the late 1980s and early 1990s (Munck, 1988, 2009; Waterman, 2012). As Marcus Taylor (2009: 436441) notes, Global Labour Studies differs from NILS in that GLS considers the feminisation of work globally and explores the "self-organising potential of workers, particularly in non-traditional sectors" and outside formal trade unions; see also Taylor and Rioux, 2017).

${ }^{3}$ An example of the waning capacity of and commitment to labour transnationalism can be seen in the responses of unions to new free trade agreements. There have been some policy statements and lobbying efforts around the Comprehensive Economic and Trade Agreement (CETA), the Canada-Colombia Free Trade Agreement and others. However, unlike in the 1990s, today there is very little activity by union members themselves in opposition to these agreements. For example, discussions within unions about agreements like the Trans-Pacific Partnership (TPP) have been limited and have not involved substantial efforts to mobilise workers' resistance or to provide resources for members to grapple with the implications of these agreements for workers' struggles globally.
} 
changes in the way unions are organised and how they bargain.

In this article, I draw from my broader research on labour internationalism in Canada to suggest that rather than seeing the lack of substantive moves toward transnational unions or transnational collective bargaining as a failure, we should step back and critically consider some of the underlying dichotomies within this narrative. Starting with a discussion of the dichotomies that characterise the literature on labour transnationalism, I argue that we might instead examine histories of solidarity practices with a view to their transformative features. Drawing upon the work of geographer Rebecca Johns (1998), I argue that this lens helps to overcome some of the dominant dichotomies to provide insights about how transnational labour practices can be transformative within wider struggles for workers' and social justice. Finally, I explore why lessons identified through this lens are urgent as we face the growing popularity of far-right movements.

\section{Setting Aside Dichotomies}

For some, transnational solidarity is a logical response to the rise of multinationals and their efforts to reorganise global production. In this framework, organising transnationally is presented as an answer to the challenges (and opportunities) created by the way workers have become connected across supply chains, sometimes even sharing a single employer (Bronfenbrenner, 2007; Harrod and O’Brien, 2012; McCallum, 2013; Anner, 2015). By scaling up through union mergers, transnational campaigns and coordinated bargaining, unions can then increase their power by organising their struggles at a scale that matches the size and reach of these companies. For others, renewed interest in the possibilities for strengthening labour transnationalism is linked more generally to hopes for new strategic openings for collective action in response to neo-liberalism as a global political force, or as a necessary component of strengthening anti-capitalist movements (Collombat, 2011; Kay, 2011).

Since the rise of New International Labour Studies (NILS) in the late 1980s (Waterman, 1987, 1989; Munck, 1988, 1999), and through the recent rise of Global Labour Studies (GLS) (Lambert, Webster and Bezuidenhout, 2012; Waterman, 2012; Brookes and McCallum, 2017; Taylor and Rioux, 2017; Webster and O'Brien, 2020; Nowak, 2021), there have been numerous debates about the purpose and promise of labour transnationalism. Aside from the more practical debates on the efficacy of specific strategies or the appropriate levels of interaction between scales of action, there is also a larger debate over the necessity and even possibility of transnational labour organising altogether. This is not surprising given that labour transnationalism as an idea and practice not only challenges the dominant cross-disciplinary methodological nationalism within the study of work and workers' resistance, but also questions the way workers' organisations are currently constituted.

Underlying this larger debate about the possibility of labour transnationalism are two interrelated dichotomies. First, there is the thread within the literature that explains the limitations of labour transnationalism as fundamental. In response to the promise and expectations developed in the late 1980s and 1990s, a debate emerged over the extent to which transnational labour solidarity was possible at all. An example of this is the debate within this journal and Critical Sociology between 2010 and 2011 with contributions by Michael Burawoy (2010, 2011), Eddie Webster (2010), Robert Lambert (2010), Ronaldo Munck (2010), Donella Caspersz (2010) and Peter Waterman (2011), or the more recent roundtable discussion on Ronaldo Munck's essay "Workers of the World Unite (At Last?)" as part of the Great Transition Initiative. ${ }^{4}$

\footnotetext{
${ }^{4}$ See https://greattransition.org/publication/workers-world-roundtable.
} 
Countering the optimism of the 1990s, the pessimistic side in these debates frames transnational labour solidarity as extremely limited, if not entirely utopian. The arguments include structural and logistical issues, political and ideological barriers, and more fundamental issues regarding the changing nature of capitalism itself and the role of waged labour within it. For instance, in Victor Silverman's (2010: 150) review essay of new political and economic strategies for building labour transnationalism, he argues that in the case of unions, "despite mergers and rebranding, the story is just bad". Silverman points to the success of neo-liberal institutions in coopting the claims of activists, the ineffectiveness of the World Social Forums as a site for crossborder organising, and the continuing decline in union density worldwide as evidence that the optimism of the 1990s was unfounded. Similarly, Michael Burawoy (2010: 302) argues that transnational practices remain organised "within the limits of capitalist hegemony" and therefore do not pose any serious threat to it. In the Canadian context, this has been echoed by Sam Gindin (2016: 294), who goes further by claiming that efforts towards transnational bargaining or international labour standards have "limited salience" and "ultimately only offers slogans - and often empty or even dangerous slogans at that". And more recently, in an online discussion facilitated by Ronaldo Munck, even Peter Evans (2019), who has been a champion of labour transnationalism, expressed his growing pessimism due to the rise of right-wing populist movements. The scepticism with regard to labour transnationalism is also reflected more generally in the nationally oriented study of work and labour which continues to be predominant within the labour studies and industrial relations scholarship (Nastovski, 2016b).

On the optimistic side of the scholarship, we see a range of studies that have emerged to create the field of Global Labour Studies, including this journal itself. The basis for optimism included everything from what was identified as a growing consciousness among rank-and-file workers about the impacts of international institutions and trade policies on local working conditions, to the successes of specific transnational strategic campaigns, or forms of direct action taken by workers as part of political solidarities (Herod, 2001; Scipes, 2010, 2016; Zweig, 2016; Brookes and McCallum, 2017; Fox-Hodess, 2017; Alimohamed-Wilson and Ness, 2018; Munck, 2018; O’Brien, 2019).

There is no shortage of arguments for the real difficulties in working to build transnational labour solidarity. This is evident in the way that even those on the optimistic side of this debate consider the myriad practical and political obstacles to engaging in this work (Hyman, 2005; Munck, 2010; Waterman, 2012; Fox-Hodess, 2017). The main difference between the optimistic and pessimistic positions, then, is the conclusions they reach based on the analysis of the obstacles. On the pessimistic side, the prevailing conclusion is the need to abandon transnational strategies altogether.

While labour transnationalism has not developed to the level expected (Waterman, 2005; Wells, 1998; Munck, 2002), efforts to build transnational solidarities and coordination continue to develop on multiple fronts (Zweig, 2005, 2016; McCallum, 2013; Marshall, 2015). Given the ongoing emergence of these new forms of transnational solidarity and coordination, the conclusions reached by the pessimistic side of this debate do little to help us analyse and evaluate the development of transnational practices. Instead, this conclusion, by foreclosing labour transnationalism as worthy of study or practice, serves to reinforce the local or national terrain as the only viable space for action. And so, this conclusion operates within another underlying dichotomy, that which juxtaposes local and global scales.

The dichotomy established between "local" and "global/transnational" has been at the centre of debates across disciplines since the early 1990s. Within these debates, scholars have challenged 
the validity of this juxtaposition and its usefulness in facilitating a deeper analysis of what may constitute an effective strategy in a particular struggle or for building the confidence and capacities of workers more generally. Within this juxtaposition there is sometimes a presumption that transnational practices undermine the building of strength locally. Examples of this include the way transnational practices may siphon off much-needed resources or capacities or in the way they can be used by union leaders who may substitute rhetorical internationalism for local militancy (Gindin, 2016). This either/or framing of local and global, much like the pessimist/optimist debate, concludes with the privileging of the national sphere as the viable terrain for action or as that which must come first (Burawoy, 2010; Gindin, 2016). As Sam Gindin (2016: 306) argues, "without strong unions within states [internationalism] will remain at the level of rhetoric and/or posturing". This argument only works logically if we first accept the inherent dichotomy. If we do accept this framing, then labour transnationalism is foreclosed as a viable sphere for struggle.

In contrast, Ronaldo Munck (2000: 15) suggests, "internationalism does not entail forsaking the national terrain, as a mystical understanding of globalisation as the new terrain superseding all others". Just because in certain cases proximity matters in winning a battle, it does not mean that the transnational must be dismissed a priori as utopian. We must ask, can the local and transnational even be so easily disembedded to be clearly juxtaposed? These spheres continually intersect. And even when these spheres can be disembedded, does assessment of strategy demand a choice between scales? In the Canadian case, for instance, how does one disembed the local from the global? As a white settler colony, everything from capitalist and state development to class formation to the evolution of trade unions has been and continues to be shaped by transnational forces.

The juxtaposition between local and global is made possible through what Waterman identifies as the assumption of "a world of nation states and orderly industrial relations which is either dying or never existed in most of the world" (quoted in Munck, 2010: 255). Or, as Dana Frank (2004: 97-98) argues, dominant conceptions of internationalism assume "a set of closed boxes, tidily bounded by nation states out of which workers reach hands across seas or national borders. The boxes themselves, though, straddle nations".

When considering transnational labour solidarity, we also need to ask whether we can separate the construction of national or local terrain from legacies of colonialism, imperialism, slavery and capitalist development (Sharma, 2001, 2005, 2006, 2007). By privileging a national or local terrain constructed through these histories, do we not reinforce the hierarchies between the workers these processes have produced and continue to produce? A clear example of this is in the function of borders. As Davina Bhandar (2004) describes, borders create a fortress for states in the North, which Sharma (2006) argues maintains a global apartheid for workers. ${ }^{5}$ How, for instance, in this era of massive global migration can we understand discreet "national" working classes as somehow separate from transnational forces? Similar to the way business unionism ideologically separates the bargaining table from wider political forces, a carte blanche refusal of transnationalism is premised on an ideological border drawn between the local and global. Reinforcing this dichotomy has consequences. ${ }^{6}$ As Peter Waterman (2005: 210) notes, internationalism is not only about relationships "between workers in distant places, it is a value without which labour and unions are

\footnotetext{
${ }^{5}$ The debate over the ways in which borders maintain global hierarchies between workers based on colonialism, imperialism and slavery is beyond the scope of this paper. Please see Bhandar (2004), Nastovski (2016b) and Sharma (2001, 2005, 2006, 2007).

${ }^{6}$ This is an important issue which I cannot sufficiently elaborate on here.
} 
imprisoned within the capitalist state-nation". Can there be an emancipatory vision for workers and social justice within a framework that delimits struggle to the national terrain?

\section{Reorienting the Lens: Critical Considerations of Labour Transnationalism as a Transformative Practice}

While I argue that the dichotomies constructed through these debates foreclose analysis, they do raise an important issue - that is, the need to develop a critical lens to transnational practices. What may be more productive then, would be to draw upon the critiques raised to create a more nuanced and historically grounded framework for evaluating ongoing efforts to build transnational labour practices. There are numerous studies that evaluate the efficacy of specific transnational practices (Herod, 2001; Webster, Lambert and Bezuidenhout, 2008; McCallum, 2013). These tend to focus on strategy and whether workers achieved their stated economic or political goals, thereby offering practical insights for organisers when thinking through the process of building transnational strategies. The basis for evaluation often focuses on the strategic value of specific campaigns or lessons from organising efforts. One limitation of this approach is that it does not necessarily consider the value of these practices within the broader goal of worker emancipation. As some in the pessimist camp point out, transnational labour solidarities are not necessarily emancipatory. As Rebecca Johns (1998: 256) argues, transnational practices can simply be extensions of business unionism and operate to accommodate rather than transform social relations, "while reasserting the dominance of a particular group of workers within capitalism's spatial structures". Some transnational campaigns can be recognised as economic successes for a specific set of workers, while simultaneously reinforcing the efforts of capital to engender competition between workers in different locations (Johns, 1998). In such cases, we see "messages of brotherhood and sisterhood clash with messages of self-preservation at any cost" (Johns, 1998: 253). As Piya Chatterjee (2009: 134) argues, such practices can operate to "mask the geopolitics of empire". The most obvious example can be seen in historical and present manifestations of labour imperialism, where some unions in the Global North have explicitly sought to undermine the interests of workers in other countries (Scipes, 2010; Bass, 2012).

If, as Waterman (2004) suggests, we need to centre emancipation as our goal, then we have to break from the dichotomous approach and critically examine the various ways the local and the global are interconnected and how this diversity of class situations conditions opportunities for struggle. As Munck (2019) argues, rather than pessimism and optimism, "is it not more about potentialities and a realistic appraisal of what is going on within the labour movement"? Such an appraisal would entail complicating our understanding of what constitutes successful strategies for building workers' power. While we no doubt want transnational strategies that lead to economic victories, transformative transnational solidarities need not (necessarily) lead to economic victories. Like in the case of Marxist writing on the transformative potential of trade unions themselves, even unsuccessful strikes can be transformative in other ways. As Engels (1845) argues, strikes can operate as schools of war for the working class. Following from Marx, if we are thinking about worker resistance with a view to emancipation, then the specific economic victories of this or that trade union do not necessarily tell us about prospects for transformative change. For Marx, the economic potential of trade unions is inherently limited by the market (Hyman, 1971). However, Marx clearly argues that the objective economic limitations of trade union action do not translate into abandoning unions as a space for organising working-class resistance. And this is because for 
Marx the value of unions is not restricted to their ability to win within the market but in their political potential in the process of building worker power - that is, in the way unions can build the capacities, consciousness and confidence of workers to resist (Hyman, 1971).

Adopting a view to emancipation then means evaluating transnational practices not on the apparent victory or failure of a specific campaign alone but also on how these practices can operate to transform the workers involved. It is this transformative potential, the way solidarity can be a site of building strength and capacity to resist and for challenging hegemonic ideas and social relations that serve capital, that makes it such an important space on the left. Like strikes and unions themselves, genuine acts of international solidarity can hit at the root of capital's ability to perpetuate competition between workers.

Drawing from Johns' work, I argue that an analytic framework that centres workers' emancipation can offer us a different way of seeing and evaluating practices of transnational labour solidarity. For Johns, this framework requires a longer view to the history of class formation and relations. This entails challenging the logics of nationalism and imperialism, which, she argues, work to privilege interests that are spatially derived over those that are class-based (Johns, 1998: 256). Johns suggests that transnational solidarities that challenge these logics are transformative rather than accommodating of the existing configuration of global inequalities between workers. This framework, like Waterman's, emphasises the limits of the national terrain, in the ways it reinforces existing hierarches embedded within the history of global class formation and leaves workers stuck in endless competition for jobs and investments. For Johns (1998: 256), transformative solidarities entail the actions of workers in one place helping others without expectation of reciprocity or benefit. While these can be a feature of strategic transnational campaigns and coordination, identifying transformative transnational practices necessitates looking beyond strategic practices that have resulted in explicit economic successes - that is, collective bargaining. David Featherstone's contributions on this are also useful for thinking through how we might evaluate and analyse the emancipatory potential of transnational labour solidarities. Featherstone (2012: 5-8) argues that solidarity itself can be a transformative relation "that shapes different ways of challenging oppression and inequalities", and produces new configurations of political relations that re-think the boundaries of working-class political practice. A good example of a political form of international solidarity organising is that of US Labor Against the War (Zweig, 2005, 2016; Scipes, 2010). Their efforts to organise workers against the Iraqi war and connect with the Iraqi labour movement served to shift the narrative of the war and the scope of what constitutes workers' issues, while reshaping struggles locally, serving as what Gramsci would call a counterhegemonic force. ${ }^{7}$ For instance, they were able to make direct links between imperialism, militarism and the gutting of social services locally. And so, if we centre a view to emancipation in our evaluation of transnational practices we need to complicate and expand our understanding of what constitutes successful action.

The evaluation of transnational action, then, means paying attention not only to economic strategies and their failure or success but also to a wider vision of the impacts of transnational labour solidarities as part of a broader transformative project inside workers' movements. As Featherstone (2012) notes, this can manifest in the way these acts serve to shift horizons of struggle

\footnotetext{
${ }^{7}$ Formed in January 2003, US Labor Against the War (USLAW) was renamed Labour Against Racism and War in August 2020 to reflect the organisation's growing scope of work. It is a network of more than 165 unions, labour councils, state labour federations, allied labour organisations and union committees (https://www.labor againstracismandwar.org/about-us).
} 
and challenge ideas of who is and who is not an ally. It is also about reorienting the analysis to consider the ways the "local" and "transnational" interact and impact each other through the process of building transnational solidarities. This can be done by considering "the question of workers' agency at its most local level to study contemporary labour internationalism" (FoxHodess, 2017: 632). I argue that utilising the local and the development of workers' agency when analysing transnational strategies facilitates a more substantive evaluation of the transformative dimensions of transnational practices and how these can be forces that also transform the local.

\section{Expectations and Unfulfilled Dreams?}

\section{Reflecting on labour transnationalism in Canada}

Let's turn back to the case of labour transnationalism in Canada, and what an analysis outside of the dominant dichotomies can bring to our understanding of this history and its importance for organising today. After the Second World War, the Canadian Labour Congress (CLC), a federation of craft and industrial unions, developed an international programme that was explicitly linked to the Cold War and a sense of a global political war against communism. There was also an underlying rationale that undermining communist and anti-colonial struggles could support worker prosperity in Canada by allowing US and Canadian companies to retain unfettered access to markets and cheap raw materials (Nastovski, 2016a, 2016b). Material security for workers would also be ensured through the creation of social democratic state policies. This vision of workers' justice excluded and undermined the interests of workers outside the borders of the nation state, but also excluded many within it, including indigenous people, women, and non-white and non-status workers. As Dana Frank (1999: 126) notes, “'Them' and 'Us' demarcated not just Americans and Communists, but white male workers privy to the boom vs. everyone else".

As the early neo-liberal period approached, the international terrain came to be seen as threatening the future material security of workers in Canada. However, this did not significantly change the strategies and vision of institutionalised labour internationalism. The anti-communist thrust of the programme waned slightly and a strong programme of partnership with the state and capital became a more cautious partnership. For instance, the CLC called for some oversight of emerging multinationals (Nastovski, 2016b). This was despite the fact that, as Charlie Post (2010: 24) argues, by the mid-1970s it was becoming clear that the "benefits to the working class of industrialised countries from imperialist investment were neither automatic nor evenly distributed". And so, a new way of looking at the global context was emerging. However, official policies and practices remained far out of reach for rank-and-file union members and largely divorced from the struggles in which they were engaged.

In the 1980s and 1990s, political solidarities with workers in Cuba, Chile and Argentina expanded to include grassroots solidarity organising on a wide scale. This organising, described as worker-to-worker solidarity, focused on mobilising rank-and-file union members in solidarity actions, and operated as part of a larger effort to challenge the logic of social partnership. Labour militancy in this period was in part linked to the rise of Canadian left nationalisms; ${ }^{8}$ while in some cases a more critical view of the nation state form emerged through transnational organising, most

\footnotetext{
${ }^{8}$ A common element of Canadian left nationalisms is a critique of American imperialism and a belief that socialism required the building of a strong national movement and economy independent from the United States (for more see Kellogg, 2015; Nastovski, 2016a, 2016b).
} 
efforts were framed as inter-national. Then, with the end of the Cold War, there was a growing sense that unions were entering a new era for international affairs. In part, this was because international labour institutions were being reshaped, allowing for more decision-making power outside high-level leadership and staff. This sense of a new era was also linked to the hope that there could now be a more united front with respect to international affairs across and within unions (Nastovski, 2016a, 2016b). International policies and practices had long been sites of heated battles, not only ideologically but also in terms of what practices could consist of and who could lead them. Over the past twenty years, there has been a waning commitment to developing transnational labour practices within unions. This is not to say there has not been significant organising in the period, but these efforts have declined in comparison to the heights of the 1980s and 1990s.

Today, transnational solidarities continue to be built within both public and private sector unions. These efforts include strategic, economically oriented transnational campaigns, networks and exchanges between workers across a single employer, and engagement in forms of political solidarities (Marshall and Garcia-Orgales, 2005; Nastovski, 2014; Marshall, 2015, 2020; Cameron et al., 2020). Like most union movements in the Global North, the transformation of transnational organising may be seen as a failure if viewed from the expectations of the creation of coordinated transnational collective bargaining or transnational unions. Even significant efforts like those of the United Steelworkers (USW) to facilitate deeper ties between workers and with social movements across an industry or employer did not translate into ongoing transnational union coordination in the ways envisioned in the 1990s (Marshall and Garcia-Orgales, 2005; Marshall, 2015, 2020).

There are many reasons why the impressive level of organising within Canadian unions in the 1980s and 1990s did not translate into significant institutional change in the direction of transnational unions and bargaining. These include many of the same reasons that those on the pessimistic and optimistic sides of the debate on labour transnationalism have identified as hindering these types of transformations in other parts of the Global North (Munck, 2002; Waterman, 2005; Burawoy, 2010; Scipes, 2010; Silverman, 2010). In the Canadian case, these obstacles included everything from the ongoing offensives by capital that threatened the very existence of unions, to the post $9 / 11$ political climate, to waning funds, commitment and capacities internally. More recently, diminishing capacity and commitment to labour transnationalism has been augmented by the dismantling of the Canadian International Development Agency (CIDA), a federal government agency that provided matching funds for union development projects with counterpart unions internationally. This has created a crisis for the institutional transnationalism of the CLC, and for affiliates who have engaged in international development aid projects funded in large part by CIDA.

\section{Labour transnationalism as transformative practice}

Now, if we examine this history within a wider view of worker emancipation, then we might change the narrative of failure by questioning whether the movement toward transnational bargaining and global unions is necessarily a progression from the more explicitly political solidarities of the 1980s and 1990s. Why does this matter? By challenging the idea that political solidarities are stepping stones towards strategic economic forms of labour transnationalism, we may rethink the role that transnational political solidarities can play inside workers' organisations. More specifically, this lens allows us to recognise the transformative role that political solidarities can play. Reflecting on the Canadian case, I argue that if we examine the height of worker-to-worker political solidarities in 
the 1980s and 1990s we can identify important lessons regarding the role that political forms of transnational solidarity can serve, especially as an important counterpoint to rising right-wing populism.

Within the Canadian context, political forms of transnational solidarity became predominant in the early neo-liberal period. As has been noted by Waterman (1987, 1998, 2005), Munck (1988, 2002) and others, what was happening inside Canadian unions in the 1980s and 1990s was part of a wider phenomenon happening within numerous trade unions in the Global North at the time what has been called new labour internationalism. At the heart of this approach was an emphasis on the mobilisation of international solidarity actions among rank-and-file activists as well as building links with social movements.

The most significant areas of solidarity organising inside Canadian unions in this period included solidarity with those confronting dictatorships, such as in South America in the 1970s (e.g., Chile, Argentina). In the 1980s key areas of solidarity focused on Central American struggles (Nicaragua, Guatemala, and El Salvador) and opposition to South African apartheid. Then in the 1990s, with the negotiation of the North American Free Trade Agreement (NAFTA), this work focused on challenging free trade agreements and building relationships with workers in Mexico.

In this period, activists engaged in a range of transnational solidarity practices, from education work with members to mobilising political solidarity actions (Nastovski, 2016a). This organising had significant reach inside Canadian unions, involving new alliances and networks of trade unionists with capacity for regular national speaking tours, days of action and major cross-union delegations to Central America. By the late 1980s, this work would become more institutionalised in the structure of certain unions and federations. In the province of Saskatchewan, activists involved in grassroots international solidarity organising set up a network of unions to coordinate international work. Several major affiliates, the Canadian Union of Public Employees (CUPE), the Canadian Autoworkers Union (CAW) and the Canadian section of the United Steelworkers Union challenged the CLC's exclusive jurisdiction on international affairs by setting up their own funds and/or committees to engage directly in international activities. These programmes worked to balance member education and mobilisation with development aid projects, funded in part through CIDA.

Ideologically, the decentralisation of international policies and practices made space for a much wider range of positions and actions across unions. For instance, in committees of labour councils or provincial unions, member activists could now build more substantial institutional links with community-based solidarity movements. The focus was primarily on political solidarities and was not aimed at building coordinative transnational strategies.

By the late 1980s, these efforts by trade union activists had led to a considerable overhaul of the institutional landscape for labour internationalism, creating new structures and political space for a different kind of engagement with the international terrain (Nastovski, 2016a, 2016b). The impact of this organising, however, went much deeper. The worker-to-worker model of labour solidarity, central to the organising of grassroots labour solidarity in Central America and against South African apartheid, advanced a new model for transnational labour action while serving to significantly remake the dominant institutional practices within Canadian unions. The political and institutional space won to substantially democratise decision-making and activity in the international sphere was directly connected to how activists organised. The ideological landscape, heightened awareness and activity was rooted in the transformative features of organising in the 1980s. How organisers mobilised workers to engage in international solidarity in this period 
exemplifies key features of transformative solidarity, including the way the activity of solidarity was itself part of transforming the local terrain.

\section{Worker self-activity}

One of the ways this organising built local capacity was through an emphasis on worker selfactivity. Organisers went directly to workplaces to mobilise rank-and-file workers, but they did so in a way that prompted workers to use their own strategic place and power to engage in solidarity efforts within workplaces. The most significant example was the organising that led to a week of direct workplace actions against apartheid in March 1986. This was made possible after years of educational efforts and meetings with rank-and-file union members across the country (Luckhardt, 2006). It included various forms of direct action taken by workers in grocery stores across the country as well as workplace disruptions, such as the disruption of communications and transportation between Canada and South Africa that took place from 8 to 15 March 1986, involving postal, longshore and telecommunication workers (Pacific Tribune, 1986; Nastovski, 2014). This week of action involved workers risking their own livelihoods and making themselves subject to possible disciplinary action for their stand in solidarity against apartheid. This is an example of a coordinated direct action that mobilised the power of workers within the workplace, emphasising their collective power to strategically engage in economic and political disruptions. Solidarity also took the form of community actions led and organised by union activists (Freeman, 1997: 354; Luckhardt, 2006: 15).

\section{Organising new groups of workers}

This organising also brought a new group of workers into union activism and served as a site where, through direct action and community organising, these workers developed new skills, new alliances with community organisations and new visions of what was possible. Many of them went on to play important roles in their unions as activists, leaders and staff in other major mobilisations, for instance, against NAFTA and the Free Trade Area of the Americas (FTAA), and in the building of more member-directed and member-led international solidarity work from the late 1980s onward. This organising not only transformed the local terrain through the emphasis on worker self-activity but also by shifting ideas of political practice. For instance, during the solidarity organising in opposition to apartheid, organisers made explicit connections between colonialism, imperialism, race, class and the Bantustan system in South Africa (Nastovski, 2014). This also fostered an understanding that these were central to the conditions of life and work that indigenous people experienced and the way this directly benefitted capital. The emphasis on worker self-activity and the situating of colonialism and imperialism as worker issues made this campaign a site of resistance against narrow visions of union action that limited union activity to purely economic struggles by sets of workers in specific workplaces.

\section{New ways of thinking about the relationship between exploitation and oppression}

By advancing a global lens to view the relationship between exploitation and oppression, this work led to new forms of alliances and reconfigurations of local struggles. One example is the international solidarity committee of the Alberta Federation of Labour, who expanded their mandate to support the anti-colonial struggle of the Lubicon Cree. ${ }^{9}$ This solidarity organising

\footnotetext{
${ }^{9}$ The struggles of the Lubicon Cree against various forces of colonialism heated up in the 1980s. For a
} 
refused the counter-posing of local, national and international while transforming the local by drawing in anti-colonialism in Canada as an important issue for workers and social justice and for creating new alliances (Nastovski, 2014, 2016b).

This period of heightened political solidarities shows the way that member-led practices can serve as sites of capacity-building for those involved. In this way, the transformative dimensions of labour transnationalism as a political practice can operate to transcend the juxtaposition of the local and global. Rather than operating to detract from "local" capacities, they can in fact work to draw in workers who otherwise may not have been involved in their union or as new sites of learning for those already active.

\section{Lessons and Significance: The Urgency of Reviving Labour Transnationalism as a Political Practice}

Within the case of Canadian unions specifically, the financial and political crises that threaten the role of transnational labour solidarity inside our unions is an opening for rethinking and widening our view of the potential role that labour transnationalism can play in our struggles and movementbuilding. The dichotomies that continue to underlie discussions of labour transnationalism have served to prompt movements back to the national as the only feasible terrain of action. This, I argue, is a dangerous conclusion and one we see being eagerly championed by right-wing populist parties. Analysing histories of transnational solidarity through an evaluatory framework, as I have sketched quickly above, can provide lessons for thinking about the role of labour transnationalism today, and specifically how more explicitly political solidarities can operate as crucial sites of learning in this time of rising right-wing populism globally.

Unlike Evans (2019), for whom the emergence of right-wing populism is a reason for pessimism vis-à-vis the prospects of labour transnationalism, I suggest that this rise points to the urgency of revitalising transnational labour practices. When we look at the historical case of Canadian unions, transnational labour solidarities have and can serve to counter the privileging of the national terrain ideologically and politically. A recent example of this privileging is the money spent by the union Unifor to run an advertisement during the 2019 Superbowl. The ad, a response to General Motor's closure of its Oshawa, Ontario assembly plant, called on Canadians to boycott cars made in Mexico (Bickis, 2019). This type of economic nationalist strategy is nothing new, particularly for unions in the auto industry (Frank, 1999). However, it stands in stark contrast to the responses of unions to NAFTA in the 1990s, when mobilisations pushed this type of argument to the sidelines and operated to advance an anti-neo-liberal politics rooted in building relationships between Canadian and Mexican auto industry workers (Robinson, 1993, 1994; Dreiling and Robinson, 1998; Stillerman, 2003; Kellogg, 2019). The level of transnational solidarity built in the mobilisations against NAFTA countered racist narratives that pitted Mexican workers against Canadian workers. These practices operated to call into question the dichotomies that framed who was responsible and who was an ally. This stands in contrast to what is happening today.

Unions have long adopted various forms of economic nationalist strategies in the face of economic downturns, the death of specific industries or jobs, or deindustrialisation. Economic nationalist strategies advanced by unions and left parties have complex histories that are beyond the scope of this article, but it is important here to raise some issues related to these strategies.

snapshot of their long struggles against colonialism see https://briarpatchmagazine.com/articles/view/ahistory-of-struggle. 
Such strategies have at times arisen out of anti-imperialism or in response to the anti-nationalist arguments on the liberal right to justify liberalised trade and other neo-liberal policies. However, even the most progressive forms of economic nationalist strategies can still operate to reinforce sectional logic that is tied to historical entitlements related to race, gender and citizenship (Nastovski, 2016b). Based on borders and citizenship, such policies are limited as an emancipatory strategy for workers' justice in that they facilitate the maintenance of global hierarchies between workers in different locations and based on citizenship status (Sharma, 2001, 2005, 2006, 2007).

This is all too familiar today with the rise of right-wing populist parties that have been responding to economic and political crises by weaving together economic nationalist and antimigrant rhetoric. The "Italians First" slogan of Lega Nord leader Matteo Salvini captures this sentiment. The group Unions for Trump is just one example of the resonance of this vision for justice among some sections of workers in the Global North. As we see with the rise of right-wing populist and fascist movements and parties globally, the racial and national logics operating to shape a sense of cross-class communities of interest are on the rise. The populist right presents narratives of entitlement based on race and citizenship, characterising workers outside these parameters as threats, whether they be immigrants, migrants or workers across national borders. These constructions are part of a war of position on the right that is providing explanations for unemployment, deindustrialisation and precarity within the current ideological crisis for hegemonic neo-liberalism. COVID-19 is only deepening this crisis and creating more fear and insecurity as so many lose their sources of livelihood. As Frank notes, the popularity of the Buy American movement in the 1930s "rose in exact correlation with the economy's degeneration. At its core, it offered an answer to the enormous crisis of the Depression: 'foreigners' and their economic incursions were the cause" (Frank as quoted in Kellogg, 2019: 68).

While those on the nationalist left often deny connections between nation and race, when we look at the histories of economic nationalist movements inside unions, these ideas have been closely tied (Frank, 1999). As Frank (1999: x) notes regarding the case of US unions, the "movement has been inextricably interwoven with fears of alleged economic infiltration by Asians and their goods". In the case of Unifor's recent response to the shutdown in Oshawa, despite Unifor president Jerry Dias' insistence that their boycott of cars made in Mexico is not racist and is even an act of solidarity with Mexican workers against the low wages they are paid, they are ultimately asking consumers to choose Canadian over Mexican workers (Bickis, 2019). Quoting a UAW activist regarding this type of strategy, this is "just a variation of the tired old bosses' line of 'you workers fight each other for jobs"' (Frank, 2002: 37). As both Frank (1999) and Kellogg (2019: 76) note, the current choice between protectionism or neo-liberal trade liberalisation "presents false solutions". If we move beyond the underlying dichotomies that frame debates on the prospects of labour transnationalism and workers' justice more generally, neither of these options present a way forward. As Kellogg (2019: 76) notes, "without making systemic change to this inequitable structure [of the global economy], we will be unable to find a solution to the international trading system's clear dysfunctionality."

When reflecting on the possible role of transnational labour solidarities, it is now more critical than ever to build a vision that presents an alternative to the narratives being advanced by the populist right. Historical cases of transformative transnational labour solidarity show us the important role that transnational practices can play as wars of position on the left, thereby creating the basis for alternative visions of workers' justice. These practices can, as in the 1980s and 1990s in Canada, be part of a larger war of position against visions of social partnership. They can also, 
through direct worker-to-worker initiatives, operate to counter racist and xenophobic currents that resonate with some workers.

\section{Conclusion}

Finding the core dichotomies which shape discussions of labour transnationalism unproductive, I have proposed the need to develop an evaluatory framework for transnational labour practices that considers the role of transnational solidarities as part of a larger emancipatory vision of workers' justice. As Johns' (1998) proposes, such an evaluatory framework must be situated with a longer view to histories of class formation and the ways colonialism and capitalist development have operated to shape competition between workers globally. In other words, do these strategies reinforce hierarchies built on the legacies of colonialism, imperialism and slavery, and maintained through the borders of Northern nation states?

This framework operates to widen the scope of what constitutes useful transnational activity. For instance, some strategic campaigns can be successful on their face - for example, to win a particular bargaining issue - but be fully leadership-led and do nothing to build capacity among the membership. If we widen the view of success to include the ways transnational practices can be transformative of "local" space, then the impacts of labour transnationalism and how we evaluate them can also be transformed. Focusing on the way transnational organising in the 1980s and 1990s was transformative of the local terrain, I argued that transnational practices can and have served as sites for re-envisioning struggle. This is particularly important today for the possibility of building counter-narratives of justice to those of the populist right.

The current waning of transnational labour practices presents a challenge and opportunity for labour activists. In this article I have suggested that, seeing this moment as an opportunity, we can rethink the role of labour transnationalism by developing a critical lens to past practices. This approach, which challenges what I argue are unproductive dichotomies, can provide an opening for the revitalisation of labour transnationalism as a political practice. The responses that will arise in the current crisis of labour transnationalism and rising right-wing populism are yet to be determined. But as Burawoy (2010) points out, we cannot assume resistance on the part of workers. Building this resistance in the current context necessarily means confronting the narratives of the populist right and the way they are selling visions of worker security based on the maintenance of global apartheid rooted in colonialism, imperialism and slavery.

\section{References}

Alimahomed-Wilson, J. and I. Ness, I. (2018) Choke Points: Logistics Workers Disrupting the Global Supply Chain. London: Pluto Press.

Anner, M. (2015) Labor Control Regimes and Worker Resistance in Global Supply Chains. Labor History, 56(3): 292-307.

Bass III, G.N. (2012) Organized Labor and U.S. Foreign Policy: The Solidarity Center in Historical Context. $\mathrm{PhD}$ thesis, Florida International University, Miami.

Bhandar, D. (2004) Renormalizing Citizenship and Life in Fortress North America. Citizenship Studies, 8(3): 261-278.

Bickis, I. (2019) Unifor Calls for Boycott of Mexican GM Vehicles in Escalation of Oshawa Fight. Toronto Star, January 25. 
Bieler, A., I. Lindberg and D. Pillay (2008) Labour and the Challenges of Globalization: What Prospects for Transnational Solidarity? London: Pluto.

Bronfenbrenner, K. (2007) Global Unions: Challenging Transnational Capital through Cross-border Campaigns. Ithaca, NY: Cornell University Press.

Brookes, M. and J. McCallum (2017) The New Global Labour Studies: A Critical Review. Global Labour Journal, 8(3): 201-218.

Buhle, P. (1999) Taking Care of Business: Samuel Gompers, George Meany, Lane Kirkland, and the Tragedy of American Labor. New York: Monthly Review.

Burawoy, M. (2010) From Polanyi to Pollyanna: The False Optimism of Global Labor Studies. Global Labour Journal, 1(2): 301-313.

Burawoy, M. (2011) On Uncompromising Pessimism: A Response to my Critics. Global Labour Journal, 2(1): $73-77$.

Cameron, K., L. Cassleman and E. Hoogers (2020) Defending Public Services: Canadian and Colombian Workers on the Frontlines. Alternate Routes: A Journal of Critical Social Research, 31(1). http://www.alternateroutes.ca/index.php/ar/article/view/22519 (accessed 25 May 2021).

Carr, B. (1999) Globalization from Below: Labour Internationalism under NAFTA. International Social Science Journal, 51(159): 49-59.

Caspersz, D. (2010) From Pollyanna to the Pollyanna Principle. A Response to Michael Burawoy's "From Polanyi to Pollyanna: The False Optimism of Global Labour Studies". Global Labour Journal, 1(3): 393397.

Chatterjee, P. (2009) Transforming Pedagogies: Imagining Internationalist/Feminist/Antiracist Literacies. In Activist Scholarship: Antiracism, Feminism and Social Change, edited by J. Sudbury and M. Okazawa-Rey. Boulder, CO: Paradigm.

Collombat, T. (2011) Several Souths: The Dynamics of the International Labour Movement in the Americas. $\mathrm{PhD}$ thesis, Carleton University, Ottawa.

Dreiling, M. and I. Robinson (1998) Union Responses to NAFTA in the US and Canada: Explaining Intraand International Variation. Mobilization: An International Quarterly 3(2): 163-184.

Engels, F. (1845) Condition of the Working Class in England. www.marxists.org/archive/marx/works /1845/condition-working-class/ch10.htm (accessed 10 May 2012).

Evans, P. (2019) Planetizing the Labor Movement. The Great Transition Initiative. https://greattransition.org/roundtable/workers-world-peter-evans (accessed 8 May 2020).

Featherstone, D. (2012) Solidarity: Hidden Histories and Geographies of Internationalism. London: Zed Books.

Fox-Hodess, K. (2017) (Re-) Locating the Local and National in the Global: Multi-scalar Political Alignment in Transnational European Dockworker Union Campaigns. British Journal of Industrial Relations, 55(3): 626-647.

Frank, D. (1999) Buy American: The Untold Story of Economic Nationalism. Boston: Beacon.

Frank, D. (2002) Demons in the Parking Lot: Auto Workers, Buy American Campaigns, and the "Japanese Threat" in the 1980s. Amerasia Joumal, 28(3): 33-50.

Frank, D. (2004) Where is the History of U.S. Labor and International Solidarity? Part I: Moveable Feast. Labor: Studies in Working-Class History of the Americas, 1(1): 95-119.

Francisco, V. and R.M. Rodriguez (2014) Countertopographies of Migrant Women: Transnational Families, Space, and Labor as Solidarity. Working USA, 17(3): 357-372.

Freeman, L. (1997) The Ambiguous Champion: Canada and South Africa in the Trudeau and Mulroney Years. Toronto: University of Toronto Press. 
Gindin, S. (2016) Internationalizing the Struggle: From Slogans to Class Politics. In A World to Win: Social Movements and Counter-Hegemony, edited by W. Carroll and S. Sarker. Winnipeg: ARP.

Harrod, J. and R. O’Brien (eds.) (2012) Global Unions? Theory and Strategies of Organized Labour in the Global Political Economy. New York: Routledge.

Herod, A. (2001) Labor Internationalism and the Contradictions of Globalization: Or, Why the Local is Sometimes Still Important in a Global Economy. Antipode, 33(3): 407-426.

Hyman, R. (1971) Marxism and the Sociology of Trade Unionism. London: Pluto.

Hyman, R. (2005) Shifting Dynamics in International Trade Unionism: Agitation, Organisation, Bureaucracy, Diplomacy. Labor History, 46(2): 137-154.

Johns, R.A. (1998) Bridging the Gap Between Class and Space: US Worker Solidarity with Guatemala. Economic Geography, 74(3): 252-271.

Kay, T. (2005) Labor Transnationalism and Global Governance: The Impact of NAFTA on Transnational Labor Relationships in North America. American Journal of Sociology, 111(3): 715-756.

Kay, T. (2011) NAFT A and the Politics of Labor Transnationalism. New York: Cambridge University Press.

Kellogg, P. (2015). Escape from the Staple Trap: Canadian Political Economy after Left Nationalism. Toronto: University of Toronto Press.

Kellogg, P. (2019) Finding the Axis of Solidarity: Populist Protectionism and the End of the North American Free Trade Agreement. Studies in Political Economy, 100(1): 65-81.

Lambert, R. (2010) Unionism in One Country is No Longer an Option. A Response to Michael Burawoy's "From Polanyi to Pollyanna: The False Optimism of Global Labour Studies". Global Labour Journal, 1(2): 388-392.

Lambert, R., E. Webster and A. Bezuidenhout (2012) Global Labour Studies: The Crises and an Emerging Research Agenda. Labor History, 53(2): 291-298.

Luckhardt, K. (2006) Unionists and the Anti-Apartheid Struggle: Lessons from the South African Experience. Relay: A Socialist Project Review, November/December.

Marshall, J. (2015) Contesting Big Mining from Canada to Mozambique. Transnational Institute, https://www.tni.org/en/briefing/contesting-big-mining-canada-mozambique (accessed 8 May 2020).

Marshall, J. (2020) Global Networks Challenging the Power of the Mining Industry. Alternate Routes, 31(1): 268-286. http://www.alternateroutes.ca/index.php/ar/article/view/22520/18312 (accessed 25 May 2021).

Marshall, J. and J. Garcia-Orgales (2005) Building Capacity for Global Action: Steelworkers’ Humanity Fund. In Paths to Union Renewal: Canadian Experiences, edited by P. Kumar and C. Schenk. Calgary: Broadview.

McCallum, J.K. (2013) Global Unions, Local Power: The New Spirit of Transnational Labor Organizing. Ithaca, NY: Cornell University Press.

Munck, R. (1988) The New International Labour Studies: An Introduction. London: Zed Books.

Munck, R. (1999) Labour Dilemmas and Labour Futures. In Labour Worldwide in the Era of Globalization edited by R. Munck and P. Waterman. London: Palgrave Macmillan.

Munck, R. (2000) Labour and Globalisation: Results and Prospects. Work, Employment and Society, 14(2): 385393.

Munck, R. (2002) Globalisation and Labour: The New "Great Transformation”. London: Zed Books.

Munck, R. (2009) Afterword: Beyond the "New" International Labour Studies. Third World Quarterly, 30(3): 617-625. 
Munck, R. (2010) Globalization and the Labour Movement: Challenges and Responses. Global Labour Journal, 1(2): 218-232.

Munck, R. (2018) Retbinking Global Labour. Newcastle: Agenda Publishing.

Munck, R. (2019) "Workers of the World Unite (At Last)." The Great Transition Initiative. https://greattransition.org/publication/workers-of-the-world-unite (accessed 8 May 2020).

Nastovski, K. (2014) Workers Confront Apartheid: Comparing Canadian Labour Solidarity Campaigns against South African and Israeli Apartheid. Working US A: The Journal of Labor and Society, Special Issue on Building International Labor Solidarity, 17(2): 211-237.

Nastovski, K. (2016a) Worker-to-Worker: A Transformative Model of Solidarity: Lessons from Grassroots International Labor Solidarity in Canada in the 1970s and 1980s. In Building Global Labor Solidarity in a Time of Accelerating Globalization, edited by K. Scipes. Chicago: Haymarket Press.

Nastovski, K. (2016b) Towards Transformative Solidarities: Wars of Position in the Making of Labour Internationalism in Canada. PhD thesis, York University, Toronto.

Nowak, J. (2021) From Industrial Relations Research to Global Labour Studies: Moving Labour Research Beyond Eurocentrism. Globalizations, 18(1): 1-14. DOI:10.1080/14747731.2021.1874210

O'Brien, R. (2019) Labour Internationalism in the Global South: The SIGTUR Initiative. Cambridge: Cambridge University Press.

Pacific Tribune (1986) Unions’ Actions to Embargo Apartheid. Pacific Tribune, March 5: 16.

Post, C. (2010) Exploring Working-Class Consciousness: A Critique of the Theory of the "LabourAristocracy". Historical Materialism, 18(4): 3-38.

Robinson, I. (1993) Economistic Unionism in Crisis: The Origins, Consequences, and Prospects of CanadaUS Labour Movement Character Divergence. In The Challenge of Restructuring: North American Labor Movements Respond, edited by J. Jenson and R. Mahon. Philadelphia, PA: Temple University Press.

Robinson, I. (1994) NAFTA, Social Unionism, and Labour Movement Power in Canada and the United States. Relations industrielles/Industrial Relations, 49(4): 657-695.

Scipes, K. (2010). AFL-CIO's Secret War Against Developing Country Workers: Solidarity or Sabotage? Lanham, MD: Lexington Books.

Scipes, K. (ed.) (2016) Building Global Labor Solidarity in a Time of Accelerating Globalization. Chicago: Haymarket Books.

Sharma, N.R. (2001) On Being Not Canadian: The Social Organization of "Migrant Workers" in Canada. Canadian Review of Sociology/Revue canadienne de sociologie, 38(4): 415-439.

Sharma, N.R. (2005) Canadian Nationalism and the Making of a Global Apartheid. Women \& Environments International Magazine 68(69): 9-12.

Sharma, N.R. (2006) Home Economics: Nationalism and the Making of Migrant Workers in Canada. Toronto: University of Toronto Press.

Sharma, N.R. (2007) White Nationalism, Illegality and Imperialism: Border Controls as Ideology. In (En)Gendering the War on Terror: War Stories and Camouflaged Politics, edited by K. Rygiel and K. Hunt. New York: Routledge.

Silverman, V. (2010) Whither or Wither Global Labour? Review Essay of Globalization and Labor: Democratizing Global Governance by Dimitris Stevis and Terry Boswell and Global Unions: Challenging Transnational Capital Through Cross-Border Campaigns by Kate Bronfenbrenner. Labour/Le Travail, 65(Summer): 149-160.

Sims, B. (1992) Workers of the World Undermined: American Labor's Role in U.S. Foreign Policy. Boston: South End. 
Stillerman, J. (2003) Transnational Activist Networks and the Emergence of Labor Internationalism in the NAFTA Countries. Social Science History 27(4): 577-601.

Taylor, M. (2009) Displacing Insecurity in a Divided World: Global Security, International Development and the Endless Accumulation of Capital. Third World Quarterly, 30(1): 147-162.

Taylor, M and S. Rioux (2017) Global Labour Studies. Cambridge: Polity Press.

Waterman, P. (1987) The More Real Thing than Big, Big Coke: The New Internationalism. ISS Working Paper Series/General Series, 37: 1-30.

Waterman, P. (1989) For the Liberation of Internationalism: A Long March Through the Literatures. Alternatives, 14(1): 5-47.

Waterman, P. (1998) Globalization, Social Movements and the New Internationalism. New York: Mansell Publishing Limited.

Waterman, P. (2004) Adventures of Emancipatory Labour Strategy as the New Global Movement Challenges International Unionism. Journal of World-System Research, 10(1): 217-253. http://jwsr.pitt.edu/ojs/index.php/jwsr/article/download/315/327 (accessed 20 July 2012).

Waterman, P. (2005) The Forward March of Labour (and Unions?) Recommenced: Reflections on an Emancipatory Labour Internationalism and International Labour Studies. Antipode, 37(2): 208-218.

Waterman, P. (2011) Beyond Polanyi and Pollyanna - Oscar Wilde? Global Labour Journal, 2(1): 78-83.

Waterman, P. (2012) An Emancipatory Global Labour Studies is Necessary! On Rethinking the Global Labour Movement in the Hour of Furnaces. Interface, 4(2): 317-368. www.interfacejournal.net Lwordpress/wp-content/uploads/2012/11/Interface-4-2-Waterman.pdf (accessed 8 June 2020).

Webster, E. (2010) From Critical Sociology to Combat Sport? A Response to Michael Burawoy's "From Polanyi to Pollyanna: The False Optimism of Global Labour Studies". Global Labour Journal, 1(2): 384 387.

Webster, E., R. Lambert and A. Beziudenhout (2008) Grounding Globalization: Labour in the Age of Insecurity. Malden, MA: Blackwell Publishing.

Webster, E. and R. O'Brien (2020) Ten Years of the Global Labour Journal: Reflecting on the Rise of the New Global Labour Studies. Global Labour Journal, 11(1): 4-17.

Wells, D. (1998) Building Transnational Coordinative Unionism. Kingston, ON: Current Issues Series - Industrial Relations Centre Press.

Zeleza, T. (1984) Colonialism and Internationalism: The Case of the British and Kenyan Labour Movement. Ufahamu: A Journal of African Studies, 14(1): 9-28.

Zweig, M. (2005) Iraq and the Labor Movement: The Remarkable Story of USLAW. New Labor Forum 14(3): 61-67.

Zweig, M. (2016) Working for Global Justice in the New US Labor Movement. In Building Global Labor Solidarity in a Time of Accelerating Globalization, edited by K. Scipes. Chicago: Haymarket.

\section{BIOGRAPHICAL NOTE}

KatHerine NAstovski is an Assistant Professor in Work and Labour Studies in the Department of Social Science at York University in Canada. Growing out of her work as an activist, her research explores the possibilities of transformative models of transnational trade union action, solidarity and coordination. She is currently completing a manuscript entitled Transnational Horizons: Workers in Canada Enter the Global Sphere (forthcoming, University of Toronto Press). [Email: nastov@,yorku.ca] 